Celina Juda

Uniwersytet Jagielloński, Kraków

\title{
SOFIA - PARYŻ - ŚWIAT. SPECYFIKA MIGRACYJNEGO DOŚWIADCZENIA TZVETANA TODOROVA
}

Bułgarski czas wielkiej przemiany to - podobnie jak w innych krajach Europy Środkowej, Wschodniej i Południowej, funkcjonujących przez pół wieku w orbicie oddziaływań sowieckiego modelu totalitaryzmu - moment zwrotny. Skutkuje on odzyskiwaniem i przywracaniem kulturze systematycznie degradowanej pamięci rozumianej i traktowanej przez decydentów minionej epoki jako dorobek zasadnie stygmatyzowany piętnem nieprawomyślności, zdegenerowania i odstępstw od modelowych osiągnięć „nowej epoki”. Cezura roku 1989 jest więc synonimem wielkiego powrotu kultur do matecznika bohaterów ,złej tradycji”, którzy z różnych powodów byli represjonowani, a niekiedy swoje ojczyzny dobrowolnie lub samowolnie (zdaniem ówczesnej, ludowej władzy) opuścili.

W postżiwkowowskiej Bułgarii zakładano, że moment inicjacji „,nowego początku” samoistnie nabierze charakteru działań integracyjnych. Po przełomie, jak głosi fraza symbolistycznego wiersza Dimcza Debeljanowa, ,progi ojcowskiego domu” mieli więc przekraczać i być w nich witani ci, którym wcześniej nie tylko odmawiano prawa do swobodnego komunikowania się z najbliższą rodzina, ale też traktowania stron rodzinnych jako naturalnego zaplecza tożsamości rodowej/narodowej. Proces rekonstrukcji i łączenia rozproszonych elementów materii kulturowej (perspektywa zewnętrzna - emigracyjna i wewnętrzna - dodatkowo podzielona na zróżnicowane ideowo opozycyjne środowiska) nie był usystematyzowany i skoordynowany przez instytucje do tego powołane. Jeśli na przykład podjęto wysiłek pośrednictwa w odnowieniu związku z ojczystymi stronami (Ministerstwo Kultury, uniwersytety, wydawnictwa), to proces taki miał i nadal miewa indywidualny przebieg oraz zróżnicowaną narrację ${ }^{1}$.

${ }^{1}$ Interesujący wydaje się tutaj przykład Georgiego Markowa - z jednej strony wrócił on do oficjalnego obiegu kultury, bo opublikowano jego powstałe na emigracji Zaoczne reportaże o Bułgarii, ale 
Upływający czas komplikuje procesy odzyskiwania niebagatelnego dziedzictwa intelektualnego czy artystycznego - traktowanego w okresie BRL-u jako niepożądane (posługując się nomenklaturą BRL-owską: jego animatorami byli uciekinierzy, przestępcy czy dezerterzy). Podejmowanie odpowiednich decyzji o charakterze instytucjonalnym oznacza zobowiązania i deklaracje; wyartykułowanie jasnego stanowiska, czy kultura/państwo są zainteresowane kompletowaniem i upowszechnieniem w całej rozciagłości spuścizny Bułgarów (humanistyka, sztuka, literatura), o cudzo-swojskim rodowodzie, nabiera statusu choroby natręctw. Chociaż od momentu przełomu w 1989 r. minęło ponad 20 lat, pytania o to, jakie znaczenie mają tego typu przedsięwzięcia dla społeczeństwa i kultury bułgarskiej, niezmiennie pozostają otwarte.

Konfrontacja światopoglądów ideowych i artystycznych, dotąd cząstkowo czy nadal hipotetycznie rozpoznanych w Bułgarii, ma nie tylko znaczenie poznawcze. Może, i powinna, pełnić rolę skutecznego sposobu poszerzania i weryfikacji horyzontu krajowych osiagnięć w tym względzie. Analiza dorobku twórców kręgu zewnętrznego, środowisk emigranckich i porównanie go z wewnętrznym/krajowym materiałem będą probierzem pozytywnej weryfikacji części kultury i literatury czasów BRLowskich. Konfrontacja literatury podmiotu prowadzi bowiem do wniosku, że wbrew realiom zideologizowanej rzeczywistości, część środowiska intelektualnego i artystycznego obroniła własną niezależność światopoglądową i tym samym krajowy rozwój kultury nie był z definicji diametralnie odmienny/gorszy od standardów wyznaczanych przez centra europejskie.

Wprowadzenie do rodzimego obiegu dorobku bułgarskich twórców do tej pory funkcjonujących i asymilujących się z kulturami nierodzimymi miałoby więc nie tylko walor poznawczo-oceniający. Działania tego typu byłyby naturalnym dopełnieniem, wzbogaceniem i tym samym wzmocnieniem monolitycznej i hermetycznej w ostatnim półwieczu kultury bułgarskiej. Nieobecne w jej lokalnym wariancie formy czy style, konfrontowane z dorobkiem krajowym, nie są przecież wartością samą w sobie, lecz mogą stać się czynnikiem ów dorobek modyfikującym czy inspirującym jego przyszłe oblicze ${ }^{2}$.

Nie należy jednak pomijać stanowisk badaczy sceptycznie postrzegających rolę i znaczenie kultury i sztuki powstającej poza granicami Bułgarii dla rodzimej twórczości. Aleksander Kiosew uważa, że „wewnętrzne” procesy rozwojowe literatury bułgarskiej nie ulegają wielkim przemianom, gdy w ich obręb zostają wprowadzone

jednocześnie, mimo otwarcia archiwów, nie zadbano o wyjaśnienie roli, jaką odegrały służby bezpieczeństwa w zabójstwie dysydenta.

${ }^{2}$ Zdaniem Galina Tichanowa zasadnicze znaczenie dla kształtu bułgarskiego postmodernizmu miała powstająca na emigracji twórczość poetycka Nikołaja Marangozowa; zob. G. Tichanow, Literatura emigracyjna a wewnatrzkrajowy proces literacki. Uwagi o butgarskim postmodernizmie [w:] Postmodernizm w literaturze i kulturze krajów Europy Środkowo-Wschodniej, red. H. Janaszek-Ivaničková, D. Fokkema, Katowice 1995, s. 155-166. 
„alternatywne” dokonania „emigrantów”. Badacz zakłada, że mariaż ów żadną znaczącą transformacją nie będzie skutkował. W jego opinii rodzimej literatury nie przeobrazi na przykład wprowadzenie do obiegu krytyczno-czytelniczego starannie przetłumaczonych utworów Iliji Trojanowa (Austria) czy Róży Lazarowej (Francja). Kultura bułgarska nie będzie poszkodowana nieobecnością dokonań niezainteresowanych krajem protoplastów pisarzy-radykałów, którzy pisząc w obcym języku (Władisław Todorow, Iwan Stanew), nie tylko nie chca, ale wręcz nie życzą sobie, by ich utwory tłumaczyć na język bułgarski. Władisław Todorow uważa, że wprowadzanie jego tekstów do obiegu cudzo-swojej kultury udaje się, bo ruguje w nich skutecznie wszelkie znamiona bułgarskości (intonacja, zasoby idiomatyczne, składnia rodzimego języka), co osiagnął, wsłuchując się w nagrania dzieł klasyków literatury brytyjskiej i amerykańskiej, by z jednej strony „uchwycić rytm obcej mowy i rozpoznać cechy arcydzieła”, a z drugiej „pozbyć się językowych nawyków bułgarszczyzny” - już obcego dla artysty języka, więc nie zaryzykuje i nie zaakceptuje „pobułgarzania” swoich tekstów. Z definicji, jedynym odbiorcą jego książek jest czytelnik anglojęzyczny.

Ważna dla czasów transformacji tematyka emigrancka/quasi-emigrancka, opis kulturowych powrotów, niezbyt licznej, ale aktywnej twórczo grupy tych, którzy przed laty znaleźli się na obczyźnie (decyzje o wyjeździe z Bułgarii podejmowali swego czasu ich rodzice), sukcesywnie nabiera całościowego kształtu.

Nie należy przeceniać roli każdej wypowiedzi powstającej poza granicami Bułgarii i doszukiwać się w niej zasadniczego, by nie powiedzieć ekstremalnego wpływu na kształtowanie się procesów kultury „rodzimej”. Każdy przypadek znacząco uzupełnia i systematyzuje katalog dziedzictwa stygmatyzowanego przez BRL-owskich aparatczyków. Jeśli wziąć pod uwagę odzyskiwanie i powroty do rodzimego socjum kultury osiagnięć intelektualistów, których dorobek w zakresie szeroko pojmowanej humanistyki ma uniwersalne znaczenie dla rozwoju myśli antropologicznej, kulturoznawstwa czy literaturoznawstwa, to najważniejszymi bohaterami interesującej nas narracji bułgarskiej są Tzvetan Todorov i Julia Kristeva³. Prace obojga tuzów europejskiej humanistyki, powstałe poza granicami Bułgarii, do rodzimej kultury inkorporowano w thumaczeniu na ojczysty język dopiero po $1989 \mathrm{r}$.

Centralny punkt niniejszych rozważań stanowi postać wybitnego humanisty europejskiego, refleksja i autorefleksja dotycząca Tzvetana Todorova, narracja na temat doświadczenia jednostki, której credo życiowe determinowała wola funkcjonowania

\footnotetext{
${ }^{3}$ Warto wspomnieć o roli i miejscu, jakie zajmuje w bułgarskiej przestrzeni kulturowej spuścizna ich poprzedników, reprezentantów starszego pokolenia - Stefana Grueva czy Stefana Popowa, uchodźców i emigrantów w sensie dosłownym, których do opuszczenia ojczyzny zmusiła historia, dziejowe zmiany systemu polityczno-społecznego po wkroczeniu w 1944 r. do Bułgarii wojsk Armii Czerwonej; zob. C. Juda, Strażnicy pamięci o niegdyś wolnej Bułgarii. Emigranckie biogramy reprezentantów pierwszej fali powojennej emigracji bułgarskiej (1944-...) [w:] Stowiańskie diaspory. Studia o literaturze emigracyjnej, red. C. Juda, Kraków 2009, s. 73-82.
} 
w świecie afirmującym swobodę, a tak zorganizowanym, aby umożliwić jej odpowiedzialne praktykowanie wolności twórczych. Dla niego samego oznaczało to przez dwie dekady budowanie wszechstronnej refleksji dotyczącej literatury i języka, struktur narracyjnych i sensów modalności w dziele artystycznym. Później skoncentrował się na egzegezie kondycji i opisie sposobów funkcjonowania jednostki we współczesnej kulturze, komentarzu doświadczeń społeczeństw poddanych opresjom totalitaryzmów XX w. (obozy koncentracyjne, procesy polityczne) lub aspektów moralnych egzystencji ludzkiej (ze szczególnym uwzględnieniem wielopostaciowej natury tożsamości jednostki). Jak zauważa Julia Jordanowa, po 20 latach uprawiania immanentnej krytyki literatury, po pierwszym „strukturalistycznym” okresie nadszedł czas niezależnej „,dialogicznej” krytyki kultury. Stało się tak, gdyż zdaniem samego Todorova: ,z biegiem lat intelekt humanistyczny czuje się zobowiązany nie tylko opisywać, ale też praktykować humanistyczne wartości”’. Aleksander Kiosew zwraca uwagę, że natura ludzka wariantywnie funkcjonuje w granicach kulturowo-historycznych, ale jednocześnie prawda i sprawiedliwość dla Todorova nie są fundowane ani na totalizującej, jednej i uniwersalnej postaci „natury ludzkiej” z epoki oświecenia, ani na anarchizującym modelu doby romantycznej. Dzieje się tak, gdyż autor Podboju Ameryki z jednej strony zakłada wyjątkowość Człowieka, ale z drugiej - uzmysławia sobie i innym, że nie da się zignorować doświadczania żywiołu współczesnego, wielopostaciowego charakteru społeczeństwa/ społeczeństw (dylematy dotyczą np. wyboru i sposobu artykułowania treści referatu wygłoszonego na XII Międzynarodowym Kongresie Slawistycznym w 1981 r. i sposobu funkcjonowania - także w 1981 r. - w czasie pierwszej wizyty w ojczyźnie po wyjeździe do Francji).

Jaki rodzaj doświadczenia podmiotu - człowieka nowoczesności interesuje Todorova? Przede wszystkim, jak formułuje to polski badacz, żywioł działań i okoliczności, które odnoszą się do „[...] do ciężkich prób, na jakie wystawiony został człowiek poddany racjonalistycznemu projektowi modernizacji oraz jego negatywnych konsekwencji (człowieka uprzedmiotowiających, ubezwłasnowolniających, dezintegrujacych czy wyobcowujących)"s, a tego typu sytuacje skutkują rodzajem opresji narażającej jednostkę na doświadczenie „konfliktu, szoku, przymusu, kontroli, represji, ekskluzji, pozostawiające traumatyczne ślady we wrażliwości jednostki" ${ }^{\text {. }}$. Ważne jednak, aby bohater tych często okrutnych, wydawałoby się - nie do przeżycia „sytuacji próby”, korzystając w całej pełni z dostępnych sposobów aktywności (podmiot jako instancja aktywna, poddana refleksyjnej samokontroli, zdyscyplinowana i autonomiczna), był zdolny do samodzielnego działania wbrew uwarunkowaniom, a niesie je sytuacja społeczno-polityczna, dyskursywne praktyki, wpisane w instytucje życia codziennego, itp., itd.

${ }^{4}$ Cyt. za: J. Jordanowa, Humanitarnijat intelekt na ,swoja” $i$,czużda” zemja (Beleżki wyrchu Tzvetan Todorov), „LiterNet” 20.09.2002, s. 1.

${ }^{5} \mathrm{R}$. Nycz, O nowoczesności jako doświadczeniu. Uwagi na wstępie [w:] Nowoczesność jako doświadczenie, red. R. Nycz, A. Zeidler-Janiszewska, Kraków 2006, s. 9.

${ }^{6}$ Ibidem, s. 10. 
Tzvetan Todorov, mimo uznania, szacunku okazywanego wybitnej osobowości europejskiej humanistyki, doświadczał swoistej traumy człowieka ,zawieszonego w czasoprzestrzeni". Przez wiele lat przy jego nazwisku twórcy biogramów, not książkowych stosowali zasadę mimikry, budując figury retoryczne neutralizujące (unikając określenia „emigrant”) lub kombinatorycznie określające tożsamościowy znak rodowodowy luminarza europejskiej humanistyki. Zanim sam zainteresowany rozwiną myśl na temat swojej naznaczonej stygmatem odstępstwa/zaprzaństwa tożsamości, najczęściej posługiwano się złożeniem: francuski krytyk literatury i teoretyk kultury pochodzenia bułgarskiego, Franco-Bulgarian philosopher, der bulgarisch-franzoesiche Wissenschaftler itp., itd.

Praktycznym wyrazem indywidualnego przepracowania przez Todorova doświadczenia totalitarnego jest trylogia: Na czużda zemja (Na obczyźnie 1998), Pamet za złoto, izkuszenie na dobroto (Pamięć zła, pokusy dobrego 2002) oraz Dytg i nastada (Obowiqzek i rozkosze 2003). (Niektórzy twierdzą że także Zdobycie Ameryki, które należałoby potraktować jako zapowiedź problematyki rozwiniętej we wspomnianych książkach).

Dyłg i nasłada to książka określana przez autora mianem intelektualnej autobiografii - pełna szczegółów z życia, które zdaniem jej głównego bohatera zasadniczo ukształtowały jego sposób myślenia i zdolność wyrażania myśli w formie pisemnej. W publikacji sfera osobistych wyznań jest jednak wkomponowana w narrację dotyczącą wydarzeń natury ogólnej, w których bohater bezpośrednio uczestniczył lub które znacząco wpływały na bieg współczesności. Interesujące, że Todorov sięga po hybrydową wypowiedź i przerzuca ciężar reżyserii formy na barki doświadczonej animatorki kultury, publicystki Catherine Portevin. Woli, aby jego wyznanie prawdy o sobie moderowała profesjonalistka często pełniąca rolę pośredniczki transakcji życiowych doświadczeń artystów, ważnych postaci francuskiego życia kulturalnego. Lista pytań, które zaproponowała ona rozmówcy, pozwoliła usystematyzować kolejno wprowadzane wątki, w naturalny sposób poskramiała żywioł nielubianej przez bohatera narcystycznej natury autobiografii.

Tzvetan Todorov, w roku oficjalnie zadekretowanej w życiu publicznym odwilży, a więc w czasie przełomowym także dla rodzimej kultury, ukończył szkołę średnią (1956) i rozpoczął na Uniwersytecie Sofijskim studia na filologii bułgarskiej, a po ich ukończeniu przez kilkanaście miesięcy (1961) pracował jako nauczyciel w prowincjonalnej szkole na wybrzeżu. Kluczowy dla przyszłej kariery badacza okazał się rok 1963 - otrzymał wtedy stypendium naukowe im. Aleksandra Teodora Bałana, co umożliwiło mu rozpoczęcie kolejnego etapu nauki - tym razem w Paryżu.

Dwa lata później z Sofii do Francji przeniosła się również rodaczka Todorova, nieco młodsza od niego, Julia Kristeva. W kraju, absolwentka romanistyki (1964), najpierw pracowała jako dziennikarka (1962-1964) w czasopismach „Narodna mładeż” i „Srednoszkołsko zname”. Od 1964 do grudnia 1965 r. była aspirantką w Instytucie Literatury BAN (literaturoznawstwo porównawcze). Wyjazd do Paryża wiązał 
się z jej zainteresowaniami teorią nowej powieści francuskiej. Kristeva pierwszych mentorów znalazła w Laboratoire d'Anthropologie Sociale/Section de Sèmio-linguistique i Centre National de la Recherche Scientifique.

Interesującym przyczynkiem dotyczącym wyboru przez Todorova miejsca zagranicznego stypendium jest rozdział książki Na obcej ziemi, zatytułowany W Paryżu. Intencją ówczesnego absolwenta studiów filologicznych był wyjazd „do Europy”, z wyraźnym wskazaniem celu podróży - stolicy Francji. Młody adept filologii znał wtedy tylko angielski, rosyjski i niemiecki, a podstawy francuskiego zaczął zgłębiać, gdy obmyślanie europejskiej wyprawy zaczęło nabierać realnych kształtów. Dotychczas Paryż funkcjonował w wyobraźni młodego Todorova dzięki opowieściom starszego o 10 lat - bułgarskiego przyjaciela - Karata. Quasi-mentor, z natury czy raczej ze względu na okoliczności egzystencji - pesymista i odludek. Adwokat, władający kilkoma językami obcymi, w prowincjonalnej kancelarii na ścianie miał zawieszoną mapę Paryża (właściwie rekwizyt bezużyteczny, bo podobno „metropolii nauczył się na pamięć” - „godzinami mógł opowiadać o osobliwościach poszczególnych dzielnic paryskich - kto w przeszłości tam mieszkał, kim są ich współcześni mieszkańcy, cytował nawet reklamy umieszczane w paryskim metrze") ${ }^{7}$.

Todorov tak komentuje „chorobę na Paryż” przyjaciela:

Myślę, że ową miłością do Paryża pałają bardzo różni ludzie w najróżniejszych krajach, z których oni sami nigdy nie wyjeżdżali. Niełatwo stwierdzić, czym karmi się owo uczucie. Książkami, reprodukcjami malarstwa (impresjonistów?). Dziennikami podróży tych, co mieli szczęście go zobaczyć? [...] Karat wtedy mi tego nie wyjaśnił, a teraz, gdy go zabrakło, nie mogę o nic zapytać (zginął w katastrofie lotniczej). Sam pytany - odpowiem - karmi się cywilizacją - słowem, które w minionych czasach było przywoływane w wyjątkowych okolicznościach i w liczbie pojedynczej, a mieściło w sobie harmonijną abstrakcyjną spekulację i było synonimem dbałości o rzeczy materialne, ostrość myśli i piękno formy. Francja uosabiała ideał cywilizowanego życia8 .

Todorov, jak wskazuje lektura jego intelektualnej biografii, przeniósł się do Francji z bagażem doświadczeń człowieka ideowo rozdartego - miał wtedy już w jakiejś mierze osobowość intelektualnie ukształtowaną, ale stale jeszcze poszukiwał celu i sensu działania na gruncie filologii. Przekonanie, że niebezpodstawnie plasuje siebie w tej, a nie innej dziedzinie, było jednak już ugruntowane. Magisterium uzyskane na sofijskiej bułgarystyce dopełniała praktyczna znajomość kilku języków obcych, a kanon lektur, jak wyznaje, uzupełniali klasycy rosyjscy oraz - choć w ograniczonym zakresie - twórczość pisarzy zachodnioeuropejskich (rzadziej w thumaczeniach na

${ }^{7}$ T. Todorov, Dyłg i nasłada - edin żiwot na posrednik. Razgowori s Katrin Portven, prewod Todorina Atanasowa, red. S. Atanasow, Sofia 2003, s. 217. Cytaty, jesli nie podano inaczej, przełożyła C. Juda.

${ }^{8}$ Ibidem. 
bułgarski; wychowanek rosyjskiego gimnazjum korzystał z pośrednictwa mowy Puszkina). Do tego dochodzily teksty filozoficzne, ,pamiątki” translatorskich osiagnięć ze źle komentowanej przez komunistów tradycji międzywojennej Bułgarii ${ }^{9}$. Innym znaczącym ogniwem edukacji młodego intelektualisty była okazjonalnie, ale $\mathrm{z}$ równym zaangażowaniem praktykowana historia malarstwa: w muzeach Moskwy i Leningradu odkrył urodę obrazów starych mistrzów holenderskich, zapoznał się z kolekcją impresjonistów, zachwycił Gauguinem. Odwiedzając brata, stypendystę Instytutu Atomowego w Dubnej (1959 i 1961), miał okazję uczestniczyć w otwartych spotkaniach z poetami - bardami „odwilżowej” rzeczywistości - na przykład Jewgienijem Jewtuszenką. Niejako przy okazji stał się właścicielem rozpowszechnianych nieoficjalnie maszynowych kopii wierszy Pasternaka (stanowiących integralną część zakazanej w ZSRR powieści Doktor Żiwago), a także niewydanych poezji Achmatowej (Poemat bez bohatera). Obdarowany zwraca uwagę, że w tamtych czasach, w żadnych okolicznościach, nie używano określenia „samizdat”, ale - jego zdaniem - tego typu przedsięwzięcia zapowiadały narodziny opozycyjnego kanonu rosyjskiej literatury ${ }^{10}$.

Ważnym epizodem ,przedparyskiej” biografii Todorova był wyjazd (1961) do Polski - podróż, jak sam zauważa, nosiła znamiona odkrywania nowej, innej niż rodzima, części Europy Środkowej (po drodze, w budapeszteńskim muzeum, podziwiał kunszt malarstwa Breughla). Pobyt w Krakowie, Warszawie oznaczał spotkania ze znajomymi, „tłumaczącymi” mu realia ówczesnego świata i racje buntowniczego charakteru społeczeństwa polskiego (skuteczniej od Bułgarów „ściśniętych w naczyniu przykrytym szczelnie ołowianą pokrywą"11 konfrontującego własne postawy z narzuconym systemem), ale największe wrażenie wywarła na nim lektura tygodników oraz, między innymi, proza Brandysa, którego osobiście pozna 30 lat później we Francji ${ }^{12}$. Wspomnienie ówczesnej wyprawy do muzeum obozu koncentracyjnego nie miało jeszcze wtedy bezpośredniego związku z jego przyszłymi tekstami na temat kondycji człowieka łagrów, skazanej na zagładę ofiary systemu totalitarnego ${ }^{13}$, ale głęboko zapadło mu w pamięć.

Tzvetan Todorov szybko zorientował się, że humanista, funkcjonując w rzeczywistości, w której stale doświadcza skutków działania syndromu ograniczenia, bo słowo wyrażające autorską myśl zawsze natrafia na barierę cenzury lub dyscyplinujące działanie autocenzury, nie ma szans na zrealizowanie projektów badawczych wykraczających poza horyzont narzuconej mu ideologii. Jak sam powiada, nienawidził polityki, a w czasie, gdy musiał dokonywać ostatecznych wyborów, reżim zdawał się rozkwitać:

\footnotetext{
${ }^{9}$ Ibidem, s. 44.

${ }^{10}$ Ibidem, s. 45.

${ }^{11}$ Fraza pojawiająca się w wielu pracach bułgarskich autorów, np. G. Sawow, Kapan za kontri. Iz praktika na totalitanija represiwen mechanizmam w Balgaria 1968-1989, Sofia 1998.

${ }^{12}$ Ibidem, s, 45.

${ }^{13}$ Chodzi o fragment książki Na czużda zemja, wydanej w 1996 r. we Francji (przekład bułgarski w 1998 r.), a dotyczącej rzeczywistości obozowej/łagrowej.
} 
Wyglądał na coś tak rzeczywistego, że aż niewzruszonego. [...] Życie w realiach reżimu komunistycznego, jako takie, miało ową wszechogarniającą konsekwencję - nie uczyniło z nas nieprzejednanych antykomunistów, ale za to przemieniło w zaciekłych anty-polityków, a dokładniej mówiąc - stworzyło ludzi, którzy z obszaru swoich zainteresowań wyrugowali jakiekolwiek zainteresowanie polityką ${ }^{14}$.

Do sfery społeczno-politycznej i aktywnego jej komentowania wrócił dopiero w latach 90., gdy zmieniły się układ i porządek świata.

W 2003 r. ukazała się w Bułgarii książka Dyłg i nasłada-edin żiwot na posrednik. Razgowori s Katrin Portven. Na odwrocie okładki zamieszczono informację, że wydawnictwo oddaje do rąk czytelnika intelektualną biografię Todorova, zaś dziennikarka, Catherine Portevin, która przygotowała i zadała jej autorowi dziesiątki pytań, napisała:

Jest bardziej francuski niż wielu naszych intelektualistów, spadek, jaki odziedziczył, czyni go w istocie najbardziej europejskim z autorów i - o czym wiedzą nieliczni - jednym $\mathrm{z}$ najczęściej tłumaczonych w świecie ${ }^{15}$.

Portevin w każdych okolicznościach prowadzonej z Todorovem rozmowy eksponuje europejskość jako cechę dominującą osobowości, tożsamości bohatera wywiadu rzeki. On sam naturalnie nie protestuje przeciwko temu, ale z drugiej strony jasno dookreśla, jaki rodowód ma nie tylko „geograficzna” cząstka jego osoby. Kwestia owa jest na tyle ważna, że wyrażona zostaje w tytule pierwszego rozdziału książki: Wieśniak Naddunajski, czyli Pers w Paryżu, Beota, ten, który przychodzi z daleka...:

Nie uważałem siebie za kompletnego nieuka, ale jeśli się pochodzi z małego kraju, zawsze dominuje naiwny punkt widzenia. W moim przypadku było i to, że - pochodziłem nie tylko z małego prowincjonalnego, ale równocześnie - komunistycznego kraju ${ }^{16}$.

Powód maksymalnego krytycyzmu opinii o jakości przymiotów człowieka z obrzeży Europy, prowincjusza (w negatywnym znaczeniu słowa), co oznaczało jawną stygmatyzację adresu rodowodowego, Todorov motywuje niskim poczuciem wartości cechującym przeciętnego Bułgara (jego zdaniem, źródeł kompleksu należy poszukiwać w historii), charakterem narodowym (skłonność do podległości/przystosowywania się i ,materializm”), geografią - położenie na obrzeżach wyrobiło w nim i jego rodakach nawyk mówienia „ruszam do Europy”, co znaczyło, że chodzi o wyprawę do „prawdziwej” cywilizacji ${ }^{17}$.

Wspomnienie o wiejskim/prowincjonalnym rodowodzie Todorova powraca w czwartym rozdziale książki: ale tutaj pojawia się figura osobnika, który już dotarł do Paryża i konfrontuje swoją tożsamość przede wszystkim z realiami natury poli-

\footnotetext{
${ }^{14}$ T. Todorov, Dytg i nastada ..., s. 42.

${ }^{15}$ Ibidem, s. 42.

${ }^{16}$ Ibidem, s. 11

${ }^{17}$ Ibidem, s. 11-12.
} 
tycznej, ze społeczną odmiennością autentycznie zaskakującą dla przybysza/niby-Europejczyka - gościa z kraju komunistycznego. Niepokoi i zaskakuje go to, że francuscy studenci czy młodzi naukowcy nie tylko nie tają przynależności do organizacji komunistycznych, ale też identyfikują się z projektem, którego fatalnych następstw Todorov doświadczył i wiedział, że nie chce go już nigdy w żaden sposób legitymizować: „Przychodziłem z kraju, który urzeczywistniał ich zachwyt [...], ale uznałem za wyzwalający fakt, że udało mi się stamtąd wydostać"18.

W tych okolicznościach Todorov z rozmysłem przyjmuje postawę antypolityczną (opowiadał dowcipy o aparatczykach, ale jeśli zauważył, że rozmowa zapowiada się na długą dyskusję polityczną, to albo próbował zmienić jej temat, albo milcząco przysłuchiwał się wywodom innych). Jak zaznacza, w latach 60 . nie interesowała go polemika na ten temat:

Miałem wrażenie, że straciłem sporo czasu - pierwsze dwadzieścia cztery lata życia - przymusowej koegzystencji z komunizmem. Teraz, gdy udało mi się uwolnić z krępujących więzów, postanowiłem, że nie dam sobie odebrać ani minuty cennego czasu ${ }^{19}$.

Nie zamierzał poświęcać uwagi światu, na którego dzieje nie miał wpływu, w którym prawdziwe intencje ludzkie skrywa maska, w którym postawy nie są wyrazem przekonań, a już z pewnością nijak się mają do prawd niezmiennych i odwiecznych. Podobne odczucia dotyczyły rzeczywistości totalitarnej, systemu, który skazuje ludzi na bezsensowne miotanie się między niskiej próby retoryką słowa publicznego a cyniczną chciwością, jednostkowymi interesami. Gdy rozmówczyni Todorova, Portevin, pyta o to, czego w latach 60. nie dało się wymazać z pamięci bułgarskiej, rozmówca wskazuje na stale dręczące go uczucie strachu (gorączkowe rozglądanie się wokól, by upewnić się, że nikt niepożądany nie jest świadkiem danego zdarzenia), traumę powracającego snu - nieudanej wyprawy z Bułgarii do Francji - w którym albo taksówka dowozi go za późno na dworzec, albo sam dworzec w ogóle nie istnieje.

Po raz pierwszy Todorov przyjechał do Bułgarii w 1981 r., dokładnie po 18 latach pobytu we Francji. Znając realia systemu, mógł obawiać się ewentualnych utrudnień w opuszczeniu kraju rodzinnego. Zapobiegając nieprzewidywalnym komplikacjom wydarzeń, posłużył się fortelem. Jako uczestnik obrad Międzynarodowego Kongresu Bułgarystycznego oraz uroczystości z okazji 1300. rocznicy powstania państwa bułgarskiego był członkiem oficjalnej delegacji reprezentującej Francję, więc zaproszenie miało charakter listu żelaznego. O wyjeździe do dawnej ojczyzny powiadomił też francuskich przyjaciół związanych lub współpracujących z mediami. W razie zatrzymania Todorova mieli oni rozpocząc akcję nagłaśniania jego sprawy. Rangę ubezpieczenia podnosiło zawarte na kilka dni przed wyjazdem do Sofii małżeństwo z obywatelką Francji - w razie komplikacji o jego powrót upominałaby się żona, a nie „tylko” konkubina.

\footnotetext{
${ }^{18}$ Ibidem, s. 126.

${ }^{19}$ Ibidem, s. 128.
} 
Owych 10 dni pobytu w Sofii, jak stwierdził Todorov, pozwoliło mu odkryć znaczenie jednego z kluczowych aspektów tożsamości ludzkiej - specyficzną kondycję jednostki (jej doznania i przeżycia), osoby powracającej do ojczyzny po wielu latach nieobecności. Zaznacza jednocześnie, że jest emigrantem z przypadku, a nie kimś, kto zaplanował i wywalczył status uchodźcy politycznego. Nie poszukiwał wygodniejszych, lepszych warunków życia. Wyjazd do Paryża miał charakter studyjny, a chęć przedłużenia o rok pobytu stypendialnego była wyłącznie podyktowana przekonaniem, że niedostatecznie zgłębił tajniki aktualnie praktykowanej przez zachodnich badaczy semiologii oraz nie zdążył ukończyć prowadzonej intensywnie kwerendy bibliotecznej. Krótka wizyta w Bułgarii, jego pierwszej ojczyźnie, nieoczekiwanie jednak zaowocowała refleksją krytyczną na temat „ojczyzny nowej”20.

Rezygnując świadomie z opisywania $\mathrm{w}$ tym miejscu bogatej i powszechnie cenionej przez gremia międzynarodowe kariery naukowej oraz osiagnięć badawczych Todorova, spróbujmy zastanowić się, z jakiego typu problemami natury świadomościowej, cywilizacyjnej zmagał się badacz, funkcjonując w tak wielu, zwykle całkowicie odmiennych od siebie, przestrzeniach cywilizacyjnych i kulturowych ${ }^{21}$. Do Bułgarii powraca człowiek i jego dzieło, ktoś, kto od kilkudziesięciu już lat nieustannie zmuszony jest odpowiadać sobie (lub pytanie to zadają mu inni) - kim w istocie jest. Najczęściej unika identyfikacji za pośrednictwem określeń „,imigrant”/,emigrant” (choć oczywiście zdaje sobie sprawę, że jest Francuzem naturalizowanym, mniej „,prawdziwym” od urodzonych w tym kraju obywateli). Gdy rzadko, ale jednak, pojawia się w rodzinnej Sofii, odwiedzając dom rodzinny czy będąc gościem środowisk intelektualnych, to jego obecność w przestrzeni publicznej jej świadkowie (media, ale też przeciętny Bułgar) plasują w aurze, perspektywie niezwykłości/wyjątkowości/ chwilowości. Sam zainteresowany nie komentuje ambiwalentnego charakteru własnej pozycji - przecież od lat funkcjonuje w licznych sytuacjach jako cudzoziemiec i nie ma ochoty, nie ma powodów tego zmieniać.

Interesujące w tym względzie wydają się komentarze, które można znaleźć na jednym z forów internetowych, gdzie dyskusja co prawda dotyczyła funkcjonowania/ rozumienia cyrylicy przez „łacińską” większość mieszkańców Europy oraz zasadności/niezasadności rezygnacji Bułgarów z tego alfabetu na przykład na forum międzynarodowym, ale przy tej okazji padło więcej krytycznych opinii dotyczących ,pamię-

${ }^{20}$ Chodzi o komentarz Todorova na temat procesów politycznych z lat 1949-1951 toczących się w sprawach uznania radzieckich łagrów za miejsca podobne do obozów nazistowskich i rolę, jaką odegrała francuska prasa komunistyczna protekcjonalnie komentująca antykomunistyczne wypowiedzi świadków, np. uchodźców politycznych z ZSRR.

${ }^{21}$ Przypomnijmy, że cezura w naukowej biografii Todorova przypada na koniec lat $70 . \mathrm{XX}$ w., kiedy to badacz odchodzi od czystego językowego literaturoznawstwa semiotycznego na rzecz nowego antropologizmu, nowego uniwersalizmu, nowego moralizmu lub humanizmu - jednocześnie rezygnując z przewodzenia święcącej triumfy krytyce postkolonialnej - środowisko nie kwestionowało, że autor pracy Podbój Ameryki jest do tego w pełni upoważniony. 
ci językowej” znanych Bułgarów, od lat żyjących i pracujących za granicą. Na temat „naszej intelektualistki”, J. Kristevej, rozgoryczony internauta pisze:

Okazuje się, że intelektualistka bułgarska już przestała być Bułgarką. Choć przez 24 lata mieszkała w rodzinnym kraju, z matką i ojcem rozmawiała po bułgarsku, dzisiaj twierdzi, że zapomniała ojczystej mowy. Została własną pacjentka, poddała autopsychoanalizie i z powodzeniem wymieniła w mózgu bułgarski na francuski. Co za sukces, co za Odyseja, Podróż! Dzieciństwo, młodość, pierwsze wspomnienia, pierwsza miłość wszystko to Kristevej udało się napisać od nowa - po francusku. Pełna autodestrukcja i ponowne narodziny w, jak sama twierdzi, adoptujących ją języku i kulturze francuskiej. [...] Skuteczne zacieranie śladów, pełna i zakończona sukcesem anihilacja. [...] Dlatego nie była w stanie podziękować za doktorat honorowy w ojczystej mowie - stąd tłumacze, asystenci - oto jak zostaje się doktorem honorowym Uniwersytetu Sofijskiego ${ }^{22}$.

Sarkastyczny komentarz autor kończy pewną radą dla tych bułgarskich emigrantów, którzy, mimo upływu czasu, nie zapomnieli mowy ojczystej, a do tej pory, choć są wybitnymi osobowościami, nie zostali docenieni w Bułgarii. Konstatuje więc:

Jeśli możliwie szybko poddadzą się procedurom metody opatentowanej przez Kristeva, metodzie trwałego zapominania mowy ojczystej, może zostaną docenieni przez stosowne instytucje akademickie. Jeśli nie jako uczeni, to przynajmniej jako eksponaty zaświadczające o skuteczności metody ${ }^{23}$.

Równie surowo jak Kristeva potraktowany został przez uczestników dyskusji Todorov. Wprawdzie pewnych fraz ojczystej mowy nie zapomniał, ale źle wypada, gdy podczas wywiadu wspiera go tłumacz, przekładający na francuski zadawane po bułgarsku pytania:

O co ci panno chodzi z tym czepianiem się Julii Kristevej? Tzvetan Todorov nie jest lepszy. Nawet on potrzebuje thumacza, bo już myśli po francusku. [...] Znane są jednak gorsze przypadki na tym uniwersytecie - w 1964 roku doktorat honorowy wręczono Hajle Sellasjemu, władcy etiopskiemu, więc i jakiejś tam Kristevej wybaczymy ${ }^{24}$.

Entuzjastycznie oceniono „pamięć ojczystego języka” w przypadku wybitnego filozofa, Petyra Uwaliewa (przytoczono w całości jego wypowiedź z maja 1997 r., miniwykładu wygłoszonego w bułgarskiej sekcji Radia BBC), Minka Bałkańskiego, profesora fizyki (wyjechał z Bułgarii w 1950 r.; po raz pierwszy odwiedził kraj urodzenia w 1991 r., by odebrać doktorat honorowy, i jedynym zauważalnym dla niego kłopotem językowym była terminologia fachowa), a także piosenkarki francuskiej

${ }^{22} \mathrm{http}$ ://forum.skycode.com/topic.asp?topic_id=42429.

${ }^{23} \mathrm{~W}$ dyskusji pojawia się jeden głos osoby przywołującej sytuację, w której Kristeva udzieliła wywiadu dziennikarzowi Bułgarskiej Telewizji i nie korzystała z pośrednictwa tłumacza - ibidem.

${ }^{24}$ Ibidem. 
z ormiańskim rodowodem - Sylvie Vartan, która w programie telewizyjnym zaśpiewała fragment piosenki zapamiętanej z dzieciństwa po bułgarsku ${ }^{25}$.

Dyskusję zamykają dwie wypowiedzi. Pierwsza dotyczy Kristevej („czarującej, lewicującej, ekscentrycznej feministki - słodkiej babuni, jakich u nas nie znajdziecie"), druga - artysty, Christa, znanego z ekscentrycznych akcji opakowywania obiektów publicznych, który nawet $\mathrm{z}$ bratem woli rozmawiać po francusku i kategorycznie odmawia rozmów na temat swoich związków z Bułgarią.

Todorov „u siebie” w Paryżu egzystuje z perspektywy dawnej ojczyzny - jak ,za granicą". W ostateczności woli określać swoją sytuację życiową pojemnym, acz nieco skomplikowanym w tych okolicznościach terminem „pośrednik”:

Zdałem sobie sprawę z tego, że żyłem jako pośrednik w różny sposób: przekraczając granice, starałem się także innym ułatwić to zadanie. Granice między krajami, językami, kulturami; granice pomiędzy sferami badań i dyscyplinami naukowymi w humanistyce. Jednocześnie granice między tym, co banalne i istotne, codzienne i odświętne, bytem i życiem duchowym. W debatach staram się być pośrednikiem. Nie znoszę manicheizmu i żelaznych kurtyn ${ }^{26}$.

Todorov, proponując refleksję na temat sytuacji jednostki wydziedziczonej z jakichś powodów z ojczystego środowiska, posiłkuje się dystansem i preferuje skrupulatną rzeczowość pozwalająca zredukować, wręcz odrzucić wszelki sentymentalizm i tym samym uniknąć banalizacji zagadnienia. Nie zawłaszcza przeżyć innych, własne doświadczenie traktuje jako uogólniająca metaforę traumatycznych losów wielu banitów żyjących w drugiej połowie XX w. Jako remedium łagodzące przeżycia ludzi odepchniętych przez wspólnotę rodową/państwową proponuje uświadomienie sobie faktu, że przecież tożsamości kulturowe nie sprowadzają się do identyfikacji wyłącznie narodowych i wszyscy (w jakimś sensie) pozostają „mieszańcami”. Z pewnością liczne grono apatrydów uzna tę propozycję za niezbyt pocieszająca, ale zdolność świadomego i refleksyjnego przeżywania siebie i swojej sytuacji w świecie kultury nieswojej, jak Todorov, posiadają nieliczni.

Zdaniem Todorova pierwsza faza egzystencji światowego prowincjusza otwierająca sytuację, w której jednostka zdolna jest funkcjonować aktywnie w drugiej, nowej ojczyźnie, jest równoznaczna z jej zgodą - mimowolną lub świadomą - na akulturację. Dzieje się tak w momencie, gdy jednostka, dzięki swemu umiejętnemu postępowaniu, osiagnie zdolność do zdystansowania się wobec własnej/cudzej kultury, co skutkuje opanowaniem jej reguł i nauczeniem się jej „mowy”. Później nadchodzi czas transkulturacji - stan określany przez Todorova ,poczuciem obcej ziemi”.

\footnotetext{
${ }^{25}$ Ibidem.

${ }^{26}$ T. Todorov, Dytg i nastada ..., s. 352.
} 
Człowiek na obczyźnie, wyrwany ze swoich ram, ze środowiska, z kraju, początkowo cierpi - przyjemniej jest mieszkać wśród swoich. Może jednak wyciagnąć ze swego doświadczenia korzyści. Uczy się nie mieszać ideału z rzeczywistością, kultury z przyrodą - to, że jakieś osobniki zachowują się różnie w stosunku do nas, nie stawia pod znakiem zapytania ich ludzkiej istoty. Czasami cudzoziemiec, urażony, zamyka się w sobie z powodu pogardliwego lub nieżyczliwego stosunku gospodarzy. Jeśli jednak zdoła przezwyciężyć te emocje, budzi się w nim ciekawość i poczucie tolerancji. Jego obecność wśród „miejscowych” wywołuje z kolei u nich efekt obcej ziemi ${ }^{27}$.

Ma rację Aleksander Kiosew, autor posłowia do książki Na czużda zemja ( $N a$ obcej ziemi), nazywając ów tekst rodzajem intelektualnej i moralnej autobiografii Todorova. Literaturoznawca bułgarski proponuje odczytać jej narrację jako specyficzną opowieść o tym, co wyjątkowe i osobiste:

- jako rodzaj konfrontacji jednostki z tym, co nie-indywidualne, osobistej życiowej trajektorii z tym, co anonimowo-kolektywne, impersonalne i wyobcowane. Todorov opisuje własne życie jako starcie nie tyle z ludźmi, co z tym, co jest przez semiotyka określane mianem ,kodów” - z kulturami, narodami, reżimami politycznymi, meandrami prawa, dylematami profesjonalnymi ${ }^{28}$.

Dominanty kompozycyjne są tutaj aż nadto znaczące - pierwszą część tekstu definiuje fraza: „Urodzony w Bułgarii (1. Doświadczenie totalitaryzmu, 2. Obozy, 3. Koniec komunizmu)”. Drugą wyjaśnia określenie: „Obywatel francuski” (tu m.in. znajdziemy rozważania na temat debat poświęconych rasizmowi, polityce intelektualistów, cenzurze i wolności słowa czy kulturze i życiu codziennemu). Nagłówek trzeciej brzmi: „Profesor na gościnnych wykładach w Stanach Zjednoczonych” (tematem jest np. krytyka literacka, humanistyka).

Dla Kiosewa książki Todorova: Na predeła (Na granicy, wyd. francuskie 1991, bułgarskie 1994), Żiwot s drugite (Życie z innymi, 1995/1998), Na czużda zemja (Na obcej ziemi, 1996/1998), są ważnym dopełnieniem jego zasadniczego strukturalistycznego dorobku. Bułgarski komentator ma przy tym pewne wątpliwości, jak zaistnieją one ze swoim uniwersalistycznym przesłaniem w przestrzeni komunikacyjnej świata, infantylnie komentującego rozmaite fanatyzmy, mitologie i mody:

Piszę wszystko to z pewnego rodzaju tęsknotą (powiada się, że taki charakter ma postmodernistyczna, a nie posttotalitarna melancholia, o której pisze Todorov). [...] Zgadzam się z Tzvetanem Todorovem, że należy rozumnie mówić o nierozumnym świecie,

${ }^{27}$ T. Todorov, Na czużda zemja, Sofia 1998, s. 21 - fragment przeł. H. Karpińska; cyt. za: http://www. translatorscafe; fragment eseju otwierającego bułgarskie wydanie książki, która pierwotnie ukazała się po francusku pod tytułem L'homme dépayseé (1996).

${ }^{28}$ A. Kiosew, Awtobiografia, antropołogia, mełancholia - posłowie [w:] T. Todorov, Na czużda zemja, Sofia 1998, s. 239. 
pisać jasno w sytuacji dominacji pustej retoryki, czerpać naukę z okropności historii, zajmować określone i odpowiedzialne stanowisko w sytuacji globalnej dominacji, wirtualizacji rzeczywistości i nadmiaru partykularnych, nieprzekładalnych punktów widzenia ${ }^{29}$.

Zawieszając w tym miejscu narrację tożsamościową dotyczącą ekspata, człowieka funkcjonującego w międzyprzestrzeni kultur, Tzvetana Todorova, przywołajmy jako puentę słowa polskiego paryżanina, Kazimierza Brandysa:

Nie jestem pierwszym człowiekiem, który mając do wyboru mieszkanie we własnym kraju lub w Paryżu, wybiera Paryż. Życie „nie u siebie” powiększa ryzyko egzystencji, ale jest też obnażeniem losu, jego gry z człowiekiem, odarciem z rzeczy niepotrzebnych. To jest ważne, bo przynosi ostrzejszą wiedzę o ludzkim bycie, który objawia się wtedy bliżej i wyraźniej niż „u siebie”. A Paryż jest miejscem szczególnym, gdzie naturalna harmonia ulic, rzeki i światła daje chwilami złudzenie szczęścia. To miasto daje pozory odwzajemnionych uczuć, rzadko tu się cierpi na skutek opuszczenia. Kiedy czuję się zagubiony w nieznajomym i młodszym ode mnie tłumie, mniej mi przykro, niż gdyby tłum rodaków popychał mnie w Warszawie. Tutaj samotność można sobie wytłumaczyć innością, obczyzną, i to jest logiczne, więc nie tak boli. Czuć się samotnym i starym w swoim kraju boli więcej ${ }^{30}$.

\footnotetext{
${ }^{29}$ Ibidem, s. 261.

${ }^{30}$ K. Brandys, Nierzeczywistość, Chotomów 1989, s. 261.
} 